\title{
Grepe uit die Eksistensialistiese Etiek
}

In die jongste tyd is die moderne mens doodbang vir alle etiese programme, vir 'n Etiek waarin vir alle mense en tye voorgeskrewe reëls, hoe 'n mens in elke situasie moet handel, gegee word. Vroeër was daar 
vaste tradisies, norme en gewoontes. Vandag is alles wankelend en relatief. Wat gister nog as sede - en daarmee as sedelik - gegeld het, geld nie meer vandag nie. Wat vandag as sede aan die orde is, sal móre nie meer daar wees nie. Daarom klop die etiese programme van die rasionalis, Rooms-Katoliek en Calvinis nie meer met die werklikheid nie. Aldus die eksistensialis.

Vroeër het die rasionalis die hele werklikheid - óók die etiese lewe - met sy outonome rede beheers en ondergehou. Daar is gemeen dat elke praktiese probleem teoreties opgelos kon word, omdat die werklikheid redelik sou wees.

Die „Aufklärung” meen egter dat die etiese lewe of praktyk nie deur die teoretiese rede verklaar kan word nie, maar wel deur die "praktische Vernunft" of "common sense" of gesonde menseverstand. Alle mense is in besit van die "common sense". Dit is 'n „sensus communis". Die gewone leek staan op gelyke voet met die hooggeleerde natuurwetenskaplike (d.i. daardie bevoorregte enkeling wat die teoretiese rede op die matesisveld skeidsregter maak), want beide het hul gesonde verstand, hul „common sense" om die praktiese probleme op te los. THOMAS REID (1710-1796) het betoog: gebruik jou „common sense” en jy sal weet hoe om eties-goed te handel.

Vandag glo die eksistensialis nie meer aan die „common sense” nie. Ook die Calvinis verwerp dit. Vir die eksistensialis is die rede en die „,common sense" 'n doding van die (eintlike) eksistensie. Vir die Calvinis het die mens geen gesonde verstand nie. Die mens het 'n deur die sonde verduisterde verstand.

Vir die rasionalis moet die Etiek antwoord gee op die vraag: HOE behoort ek te handel?

Vir die eksistensialis is dit ' $n$ valse vraag. Hy sê, as jy vra HOE behoort ek te handel, dan vra jy: v.clgens welke aprori's, wette, beginsels behoort ek te handel? En daar bestaan juis geen beginsels waarvolgens die etiese sou fungeer nie; eg. vernietig $\mathrm{lg}$.

Daarom vra die eksistensialiste HEIDEGGER, SARTRE en SIMONE DE BEAUVOIR 'n ander vraag: BEHOORT ek (eintlik) te eksisteer?

Hulle lê totale gewig op die BEHOORT... ondat die "behore" vir hulle die etiese synswyse van die mens uitmaak.

As ons fyn oplet, sien ons dat die eksistensialiste - nieteenstaande hul wrewelige verset teen alle beginsels - 'n duidelike geformuleerde beginsel in hul Etiek handhaaf: 
Hulle sê naamlik: „As jy alleen maar dié houding inneem: ek behocrt te eksisteer - maak nie saak HOE nie - dan is jou eksistrere, jou inset, jou handele as „eintlik”, as „volkome”, as „goed” te kwalifiseer!"

Die eksistensialis wou die HOE van die rasionalistiese Etiek met wortel en tak uitroei, omdat dit te veel na prinsipes geruik het. Maar die parasiet is afhanklik van sy gasheer. Luister hoedat die HOE weer stilletjies by die eksistensialistiese Etiek insluip: „As ... dan ..."

Die "eintlike" wat tot sover in hakies voor die eksistensie gestaan het, is ook 'n sprekende bewys dat die eksistensialis met 'n HOE en dus met 'n prinsipe opereer. Hy gee baie duidelik 'n beginsel aan die hand om tussen die eintlike en die oneintlike eksistensie te onderskei. Hier spreek 'n verkapte kasuistiek, 'n swak vermomde etiese program en 'n uitgediende formalisme.

Volgens die eksistensialis het die tyd eindelik deurgebreek... uit die kinderskoene in die adolessensie. Eers het die rasionalis, Rooms-Katoliek en Calvinis as kinders net die sg. objektiwiteit van die rede, van die Kerk, van die tradisie, van die sede gesien. Nou sien die eksistensialis as adclessent die sg. subjektiwiteit daarvan raak. Daar word gevra: hoekom moet ek sus of so maak?; hoekom is dit of dat nou juis die eties-goeie? Nou sien die adolessent dat hy in 'n wêreld met wankelende pilare gegooi is; ' $n$ wêreld wat onvolmaak is, wat nog gemaak moet word.

Vir die kind is daar gekies. Die adolessent moet self kies. Vir SIMONE DE BEAUVOIR kom dit glad nie aan op 'n keuse van 'n sekere moontlikheid (of op die inneem van 'n sekere houding en inset) wat deur die „common sense" of deur die Kerk of deur die etiese norm aangewys is nie ... want dan is daar mos geen keuse en dus geen menslike vryheid nie. Nee, die eksistensialis wil weer self kies; geen norme of apriori's of Kerklike instansie mag vir sy part kies nie.

Nou eers, waar die moment van kiesing opduik, is daar sprake van 'n etiese situasie. By die kind heers alleen 'n natuurlike toestand; die rasionalis, Rooms-Katoliek en Calvinis is deterministe en kan dus geen Etiek uitbou nie!

Hierdie moontlikheid om te kies, betoog die eksistensialis, moet jy troetel, moet jy aanneem, moet jy kies. Nadat jy die moontlikheid om te kies gekies het, is daar geen tweede keuse nie. Dus gaan jy nie nou heen met jou kiesmoontlikreid en kies die goeie of die slegte nie; nee 
jy bly neutraal t.o.v. die eties-goeie en die eties-slegte. Daar is net een keuse: vir of teen die kiesmoontlikheid.

DIE KEUSE LE DUS NIE TUSSEN DIE ETIES-GOEIE EN DIE ETIES-SLEGTE NIE, MAAR TUSSEN DIE ETIESE EN DIE A-ETIESE. ')

Waar jy die moontlikheid om te kies gekies het (as joune aangeneem het), daar het jy dus die etiese gekies. Word eksistensialis, want:

DIT IS GOED (!) OM DIE ETIESE TE KIES!

Hieruit vloei voort dat waar jy die a-etiese gekies het, is jou daad nóg goed nòg sleg, want "goed" en "sleg" is nie op die a-etiese kategorie van toepassing nie. Elke behorensmatige eksistensie wat gekies word, is altyd die goeie.

Uit die voorgaande merk ons dat net die eties-goeie bestaan. Die eksistensialistiese Etiek van HEIDEGGER, SATRE en S. DE BEAUVOIR loën die sonde!

SATRE sê: Niks kan vir my goed wees sonder dat dit vir almal goed is nie. Vraag: wat is vir SATRE goed? Antwoord: alleen die blote feit dat daar 'n daad, 'n kiesing (van die kiesmoontlikheid), 'n besetting, 'n verpligting, „l'engagement" is. Hierdie eksistensialistiese Etiek word dan ook die „l'engagement"-etiek genoem. Sien u die pligsetiek in eksistensialistiese drag?

Alleen die barre feit dat daar 'n kiesing, 'n daad, 'n inset is, gee die deurslag tot die goeie. Nadat jy die etiese synswyse gekies het, kan jy maar Christen wees, of Mohammedaan wees, of ateīs wees, WANT DIE, ,WAT' WORD ,GOED' DEUR DIE ,DAT'. Hartlik stem SARTRE dan ook saam: wat ook al gekies word, is dit altyd die goeie. Nee, u sien meer: 'n formalistiese pligsetiek in irrasionalistiese kleure.

Vroeër was alle etiese norme en gangbare etieke vir die eksistensialiste neutraal, sinloos, gelykvormig en relatief. Nou sluip die relativisme weer by die agterdeur in, boonop met 'n voorwaarde: eers moet jy eksistensialis word, voordat jy Christen (of wat ook al) wil word. (Hiermee hang in ' $n$ groot mate die problematiek van KIERKEGAARD en $E$. BRUNNER se sg. , aanknopingspunt' asook Rome se ,natuurlike teologie' saam).

S. DE BEAUVOIR gaan egter nie so ver om te sê: nadat jy jou behorensmatige eksistensie, jou moontlikreid, jou vryheid gekies het, kan jy maar Christen (of wat ook al) wees nie. Sy bly vashou aan die deur HEIDEGGER so kostelik getipeerde „heutiges Existenzgeschrei”. Nee, sodra jy jou vryheid, jou kiesmoontlikheid met bv. Christenwese sou vul, dan sou jy volgens E. DE BEAUVOIR dit 'n waardebepaaldheid, en 
so 'n relatiewe inhoud en sin gee. Dan relativeer jy jou kiesmoontlikheid, jou vryheid; en vir S. DE BEAUVOIR besit die mens juis absolute vryheid.

Daarom bly die eksistensialistiese etikus volgens S. DE BEAUVOIR in die adolessente krisis soos 'n avonturier: hy móát van moment tot moment 'n leë kiesmoontlikheid en absurde vryheid kies.

"The man we call an adventurer... is one who remains indifferent to the content, that is, to the human meaning of action..." $)$. "He likes action for its own sake. He finds joy in spreading through the world a freedom which remains indifferent to its content". ${ }^{3}$ ).

As adolessente avonturier verwerf die eksistensialis van kiesing tot kiesing sy etiese synswyse. Hierin stem alle eksistensialiste ooreen: die mens het van nature geen etiese synswyse nie. Die mens moet dit self skep. Die mens skep dit in daardie moment as hy sy kiesmoontlikreid kies.

Hierteenoor handhaaf ons dat die mens kragtens sy van God geskapenheid wel deeglik 'n etiese funksie of synswyse het. Nie die soevereingewaande absolute vrye mens nie, maar die Almagtige God is Skepper daarvan. Kragtens sy etiese funksie kan die mens 'n etiese akte, 'n etiese daad verrig, en nié omgekeerd soos die eksistensialis wil as sou die mens kragtens 'n etiese daad sy etiese funksie in aansyn roep nie!

S. DE BEAUVOIR bly (in teenstelling tot HEIDEGGER en SARTRE in hul tweede fase) by die formalisme tot die tweede mag. Die „blosze Faktisität" van die positivisme word hier tot 'n uiterste spankrag uitgerafel: alleen die feit van die feitlikheid tel by die beantwoording van die vraag ,BEHOORT ek (eintlik) te eksisteer?'

Die reaksie van die eksistensialistiese Etiek teen die ,gebod-opgebod-en-reël-op-reël"-Etiek wat volgens hulle by die rasionaliste, Rooms-Katolieke en Calviniste heers, is o.a. gebore uit 'n verwarring tussen sede en die etiese. Ondat die tradisie, die gewoonte, die sede verander, sou die wet vir die etiese ook van tyd tot tyd en mens tot mens verander. Elke tyd, mens en situasie sou sy eie wet vir die etiese hê in die wordende gewoontes, veranderende sedes en relatiewe etos.

Sien u die tweeslagtigheid? Die sg. eksistensialistiese etiek is 'n etos-leer en geen Etiek nie!

Vir ons is dit die sedes (d.i. histories verwerklikte gedragswyses) wat na gelang van tye, mense en omstandighede verander. Die openbaring van Gods wet vir die etiese is nie altyd oral dieselfde nie, MAAR DIE 
WET VIR DIE ETIESE BLY ONVERANDERLIK, is niè relatief nie en is soeverein in eie kring.

Watter betekenis het die wet vir die etiese vir my in ' $n$ bepaalde situasie?

Die eksistensialistiese teologiese etiek meen: God is 'n verborge God en daarom dra Gods wet ook 'n verborge karakter. Dit kan nooit vooruit gesê word wat Gods wet vir die etiese in 'n gegewe geval van my eis nie. Ook R. BULTMANN laat - in navolging van Heidegger se eerste fase - die hele Etiek opgaan in „Entscheidung”. Maar wat die beslissing materieel inhou, kan nooit gesê word nie.

Waar BARTH, BRUNNER, e.a. die tipiese kasuistiek bestry in die sin dat dit 'n logiese subsumering van die konkrete gevalle onder 'n abstrakte synswet is (by die Rooms-Katolisisme), kan ons instem. Maar ons moet onthou: daar bestaan geen "Gebot der Stunde" in die sin van diskontinuiteit van Gods gebod nie. Die Bybel roep ons nie op tot 'n gehoorsaming aan 'n "Gebot der Stunde" in bg. betekenis nie, maar tot 'n gehoorsaming aan Sy „Gebot" in die „Stunde”. En hierdie gebod bly altyd dieselfide. Dit is die stonde wat verander. Nou mag dit wees dat ons in twee verskillende momente mekaar weersprekende antwoorde gegee het. Dit is egter gevolg van die sondeval en nie van 'n sg. dialektiese karakter van die gebod nie.

By God is geen ,ja" en "nee” tegelyk nie; Hy spreek Hom nie in Sy gebod teë nie. Elke dialektiek in Gods wet sou cns verantwoordelikheid ophef.

Daar is dus nie sprake van 'n botsing van pligte in die sin dat daar deur God teenstrydige eise gestel word nie. Dit is hierdie in sonde gevalle wêreld en ook die sondige mens wat antinomiese eise stel. Uit onsself kan ons hierdie botsing van pligte nie ophef nie. Christus het ók die sondige ontwrigting van ons wêreldstruktuur oorwin en ons weet dat die botsing van pligte hiernamaals nie meer sal wees nie.

Die dialektiese teoloë is só deur die eksistensialistiese filosofie beinvloed, dat hulle in hul reaksie teen die sg. gebod-op-gebod-en-reëlop-reël-etiek alle binding aan die wet verafsku. Verkeerdelik beroep hulle hul op Paulus. Paulus het die vryheid van die Christen van die vloek en van die diensbaarheid van die wet geleer en ook elke moontlikheid om langs die weg van die wet Gods genade te verdien, afgewys. Oók het Paulus geleer dat die doel van die wet die vryheid is, dat die wet nié in die vryheid opgehef word nie, dat die vryheid die vervulling en die volheid van die wet is. 
Die erkenning van die wet (én die vryheid!) by die Calvinis sien sommige sg. Gereformeerde eksistensialiste deur die bril van genoemde etos-leer.

BARTH wil niks weet van die sg. „Schopfungsordnungen” nie en daarom is hy afkerig teenoor 'n positiewe verantwoordelikheid i.v.m. die etiese in die samelewing waarin die Christen staan. Hy is o.a. bang vir die gevaar wat by Rome in sake die natuurreg dreig, nl.: dat die sg. sedewet wat aan alle mense van nature eie is (lex naturalis), primêr is en Gods geopenbaarde Wil in Sy Woord van sekondêre belang gaan word.

Die Skriflig op wet en vryheid laat die Calvinis, sonder genoemde vrees, 'n ander taak sien: watter positiewe verantwoordelikheid het ek as Christen i.v.m. die etiese in die samelewing waarin ek staan kragtens die beginsels van die Evangelie van Christus vir die etiese verhoudinge in ons wêreldstruktuur?

BRUNNER en H. THIELICKE sien ook hul weg oop om van strukture of ordeninge te praat. Die ordeninge word as 'n ruwe wet van die natuurlik-tydelike en sondige lewe gesien. Deur hierdie sondige ordeninge onderhou God Sy wêreld. Om twee hoofredes is die Calvinis dus op 'n dwaalweg as hy praat van 'n „Christelike maatskappy", of 'n „Christelike wetenskap", of 'n "Christelike filosofie”, ens.: omdat die ordeninge sondig en leuenagtig is, is ' $\mathrm{n}$ sg. Christelike ordening 'n vierkantige sirkel. Tweedens eis God dat ons ons na die gegewe ordeninge moet skik... die gelowige en ongelowige moet skouer aan skouer arbei.

Hierdie opvatting kan ons nie aanvaar nie; eerstens, omdat God nêrens in Sy Woord so iets soos 'n gehoorsaming aan die sondige ordeninge eis nie. God se soevereiniteit is geen Occamistiese willekeur nie. Verder is die struktuurwette wat God aan sy skepping gegee het seer sekerlik nie sondige wette nie. Wat wel sondig kan wees (en so vele kere is), is die menslike positivering van die wette.

Versus Rome verklaar ons dat die strukture nooit die openbaring van Gods Wil in Sy Woord kan vervang nie; eg. moet dan ook altyd in die lig van lg. gesien word.

Versus die rasionalisme handhaaf ons dat my sondige verstand nié die lig op my etiese weg kan wees nie.

Aan die adres van die eksistensialiste (ateïste en Christelik): dit is ' $n$ van God gegewe taak om die wette in, deur en tot Christus te positiveer. 
Daarom moet ons steeds trag om in die geloof die sondige gepositiveerde ordeninge te bestry en om reformerend 'n etiese ordening te positiveer soli Deo gloria.

Inderdaad, jou kiesmoontlikheid is leeg en absurd... sonder God.

Boonop is jou kiesmoontlikheid nog geen vryheid nie. Inteendeel, dit is louter moontlikheid.

Nog meer. Ons besit nie net 'n kiesmoontlikheid t.o.v. die etiese nie, maar t.o.v. elke sfeer waarin ons staan. As Skrifgelowiges weet ons dat God in Christus se verlossing en herskeppingswerk aan ons kiesmoontlikhede in al ons lewenssfere weer sin gegee het. So het ook ons etiese kiesmoontlikheid as grond Romeine II vers 36: „Uit Hom en deur Hom en tot Hom is alle dinge."

\section{P.U. vir C.H.O.}

P. G. W. DU PLESSIS.

1) In 'n sekere mate word dit nou vir ons duidelik waarom daar tot dusver nog so weinig Etiek-werke in die eksistensialistiese filosofie-kamp geskryf is. ' $n$ Prikkelende werk in die verband is die van BEAUVOIR, $S$. de: The ethics of ambiquity. (Uit Frans vertaal deur B. Frechtman), New York, 1949.

2) BEAUVOIR, S. de: Idem, p. 61.

3) BeAuVoIR, S. de: Idem, p. 58. 